\title{
Floristic and vegetation structure of a grassland plant community on shallow basalt in southern Brazil
}

\author{
Marcelo Fett Pinto ${ }^{1}$, Carlos Nabinger ${ }^{1}$, Ilsi Iob Boldrini ${ }^{2}$, Pedro Maria de Abreu Ferreira ${ }^{2,4}$, \\ Robberson Bernal Setubal ${ }^{2}$, Rafael Trevisan ${ }^{3}$, Jean Kássio Fedrigo ${ }^{1}$ and Igor Justin Carassai ${ }^{1}$
}

Submitted: 9 July, 2012. Accepted: 17 November, 2012

\begin{abstract}
Few studies have adequately described the floristic and structural features of natural grasslands associated with shallow basalt soils in southern Brazil. This study was carried out on natural grazing land used for livestock production in the municipality of Santana do Livramento, in the Campanha region of the state of Rio Grande do Sul, Brazil. The aim of the study was to describe the floristic and structural diversity of the area. The floristic list obtained comprises 229 plant taxa from 40 botanical families, with a predominance of the families Poaceae (62), Asteraceae (28), Fabaceae (16) and Cyperaceae (12). The estimated diversity and evenness in the community were 3.00 and 0.874 , respectively. Bare soil and rock outcrops accounted for $19.3 \%$ of the area, resulting in limited forage availability. Multivariate analysis revealed two well-defined groups among the sampling units. One group showed a high degree of internal aggregation, associated with deep soils, and was characterized by the presence of tussocks, whereas the other was less aggregate and was characterized by prostrate species growing on shallow soil. Ordination analysis indicated a gradient of moisture and of soil depth in the study area, resulting in different vegetation patterns. These patterns were analogous to the vegetation physiognomies described for Uruguayan grasslands. Overall, the grassland community studied is similar to others found throughout southern Brazil, although it harbors more winter forage species. In addition, the rare grass Paspalum indecorum Mez is locally dominant in some patches, behaving similarly to P. notatum Fl., a widespread grass that dominates extensive grassland areas in southern Brazil.
\end{abstract}

Key words: diversity, richness, Pampa biome, forage species, environmental gradient

\section{Introduction}

Natural grasslands growing on shallow basalt soils cover approximately 4.5 million ha in southern Brazil (primarily in the Campanha region of the state of Rio Grande do Sul) and Uruguay (Hasenack et al. 2010). At present, most of this area is in relatively good conservation status and constitutes the main source of forage for regional beef cattle production (Bilenca \& Miñarro 2004). Natural grasslands also provide many other environmental benefits, such as fixation of atmospheric carbon (Guterres et al. 2006); nutrient storage and cycling; regulation and maintenance of water cycles and water quality; prevention and control of soil erosion; and scenic beauty (Tornquist \& Bayer 2009). In addition, due to the prevailing winds in the grassland-dominated ecosystems of southern Brazil and Uruguay, wind power plants have recently been installed in the region, contributing to clean energy generation. Because natural grasslands play such important roles, increasing our knowledge of these ecosystems and preserving them has become an ethical duty for farmers and researchers alike.

In livestock production systems that rely on heterogeneous and complex environments such as natural grasslands, identifying and understanding the biology of key plant species are prerequisites to inform decisions regarding management and sustainability, because species composition influences plant production dynamics at temporal and spatial scales (Soares et al. 2005). The result is the rise of a genuinely symbiotic integrative productive system, which combines the need to produce and the need to continue producing in the future. According to Hodgson (1990), the foundation of the management of natural grazing lands is to reconcile livestock nutritional demands with maintenance of the productive potential of grazed plants. In order to do so, it is imperative to gather knowledge of the composition and structure of the natural grazing land.

\footnotetext{
${ }^{1}$ Universidade Federal do Rio Grande do Sul, Faculdade de Agronomia, Porto Alegre, RS, Brazil

${ }^{2}$ Universidade Federal do Rio Grande do Sul, Programa de Pós-Graduação em Botânica, Porto Alegre, RS, Brazil

${ }^{3}$ Universidade Federal de Santa Catarina, Departamento de Botânica, Florianópolis, SC, Brazil

${ }^{4}$ Author for correspondence: pmaferreira26@gmail.com
} 
Despite the ecological and economic relevance of grasslands on shallow soils in Brazil, there have been only a few studies evaluating such areas, all of which have been carried out in neighboring Uruguay (Rosengurtt 1979; Berretta 1998; Lezama et al. 2006; Lezama et al. 2010). The objective of the present study was to characterize the floristic composition and structure of the plant community of natural grasslands on Lithic Ustorthents derived from basalt in southern Brazil, providing a representative floristic list for this formation.

\section{Material and methods}

The survey was carried out on private property in a rural area (Santo Antônio Farm, 31 03'29”'s; 55 55'26”'W, 327 m above mean sea level), in the Coxilha Rica district of the municipality of Santana do Livramento, in the state of Rio Grande do Sul, Brazil, in the physiographic region locally known as Campanha (Stammel 1996). Natural grasslands in the area are historically used as the main forage source for livestock production, as in most of the preserved natural grassland ecosystems in the region (Nabinger et al. 2009). According to the Köppen climate classification system, the climate in the study area is type Cfa, theoretically with no dry season, although there is a high probability of soil water deficit during the peak of summer (Leivas et al. 2006). The soil in the sampling area is a Lithic Ustorthents (Neossolo Litólico Eutrófico by the Brazilian Soil Classification System, Pedregal mapping unit; EMBRAPA 1999). Physically, the soil has low drainage and water storage capacity, featuring the frequent presence of small loose stones and larger rock outcrops. Grassland vegetation at the study site is heterogeneous, presenting different physiognomic patterns that are visually distinguishable in terms of the overall structure and species composition, as well as the presence of bare soil and rock outcrops. Based on these criteria, the studied site was visually classified a priori into four categories, or structural patterns: "soft", "open", "closed" and "indecorum".

In relief depressions with deeper soils, vegetation was dominated by tall erect species adapted to high humidity, which usually bear leaves with small amounts of silica and fibers, thus characterizing the "soft" pattern. At hilltops and on hillsides, overall vegetation height was smaller and encompassed three physiognomic patterns distributed in patches: the "closed" pattern, showing dense vegetation cover, with almost no bare soil or rocks; the "open" pattern, with large amounts of bare soil or rock outcrops; and the "indecorum" pattern, comprising vegetation patches dominated by the grass Paspalum indecorum.

Data collection for the structural survey was conducted in 90 square sampling units (SUs) of $0.25 \mathrm{~m}^{2}$ each, distributed over 77.3 ha of natural grasslands. We used preferential SU allocation to sample the four physiognomic patterns proportional to their representation in the landscape (Matteucci \& Colma 1982). An exhaustive floristic list was prepared prior to and during the structural survey by collecting plant specimens outside the SUs throughout the study area. The surveys were carried out during the spring of 2009. Specimens were identified by consulting the specific taxonomic literature (Barros 1960; Burkart 1969, 1974, 1979, 1987; Delprete et al. 2004, 2005; Burkart \& Bacigalupo 2005; Lourteig 1983; Rosengurtt et al. 1970; besides many localized taxonomic revisions and unpublished dissertations and theses) and by consulting specialists. The resulting a priori classification of the 90 SUs into one of the four physiognomic patterns was as follows: 36 "closed"; 44 "open"; 12 "soft"; and eight "indecorum". The robustness of this a priori classification was tested using multivariate analyses (see below). The sampled area has been historically managed with domestic herbivores. For all species, bare soil and rock present in each SU, cover was estimated using an adaptation of the decimal scale devised by Londo (Londo 1976). Respective scale value/real cover value were: $0.1 /<1 \%$, $0.5 / 1.1-5 \%, 1 / 5.1-10 \%, 2 / 10.1-20 \%$ and so forth in decimal intervals up to $10 / 90.1-100 \%$.

For each species, we calculated absolute and relative frequency; absolute and relative cover; and importance value (IV). For the plant community as a whole, we calculated the Shannon diversity index $(\mathrm{H}$, using the natural logarithmic base) and Pielou's evenness index (J'-Pielou 1969; Müeller-Dombois \& Ellenberg 1974; Magurran 1988).

The raw data matrix was submitted to multivariate analyses using MULTIV software (Pillar 1997). Cluster analysis was carried out with the sum of squares as the clustering criterion (Ward 1963; Orlóci 1967). After cluster analysis, we looked for well-defined groups among the SUs using the method proposed by Pillar (1999a). We employed principal coordinate analysis using chord distance between SUs. We evaluated stability and significance of the first five ordination axes after 10,000 iterations of bootstrap resampling (Pillar 1999a; 1999b). The variables "bare soil" and "rock cover" were not included in these analyses but were inserted in the ordination diagram after computing the correlation between their vectors and the ordination scores of SUs (first two axes).

\section{Results and discussion}

The floristic survey identified 229 taxa, belonging to 138 genera and 40 families (Appendix 1). The most representative families were Poaceae, with 62 taxa, and Asteraceae, with 28 taxa, accounting for $26.8 \%$ and $12.1 \%$ of the total species richness, respectively, compared with $6.9 \%$ and $5.2 \%$, respectively, for Fabaceae and Cyperaceae, both of which are worth mentioning because most of their taxa constitute important forage sources. Collectively, Poaceae, Asteraceae, Cyperaceae and Fabaceae accounted for 50.9\% of the taxa recorded in the survey. Twenty-two other families presented two to seven taxa each, accounting for $43.1 \%$ of the total species richness, and another 14 families presented one 
taxon each, accounting for the remaining 6\%. In the structural survey of the 90 SUs, we identified 178 plant taxa (see Appendix 2 for the complete list with frequency and cover values for each variable).

For the plant community studied, the $\mathrm{H}^{\prime}$ was estimated at 3.00 and the J' was estimated at 0.874 . In a study of a grassland community on sandy soils, along the banks of a seashore lagoon in southern Brazil, Boldrini et al. (2008) found similar diversity $\left(H^{\prime}=2.98\right)$ and slightly lower species richness (183). Working in that same region, Ferreira \& Setubal (2009) found higher diversity $\left(H^{\prime}=3.63\right)$ and lower richness (126). In a grassland community on predominantly shallow soils on a granite hill, also in southern Brazil, Ferreira et al. (2010) found an $\mathrm{H}^{\prime}$ of 4.5 and identified 282 plant taxa. All of those studies were carried out on sites historically submitted to grazing, burning or both, although some of them are not managed at the present.

Sandy soils and shallow stony soils are restrictive environments for the development of many species. In such environments, a small group of stress-tolerant taxa can dominate the community, thus reducing diversity and evenness. The estimated evenness for our studied community was similar to the 0.87 and 0.86 found by Ferreira \& Setubal (2009) and Ferreira et al. (2010), respectively, and higher than the 0.68 found by Boldrini et al. (2008). The relatively similar diversity, evenness and overall richness among surveys conducted at different sites within the Pampa biome provide further evidence that it constitutes a discrete ecological unit (Ferreira \& Boldrini 2011).

Bare soil and rocks accounted for $19.3 \%$ of the total sampled area. Similar values have been found for grasslands on shallow basalt soils in Uruguay (Lezama et al. 2006). Although this proportion is high, bare soil and rock cover are important, intrinsic features of Litholic Neosols (Stammel 1996) and should be taken into account when estimating forage availability.

Poaceae, the family with most taxa in our survey, accumulated $49.2 \%$ of the importance value (IV), compared with $15.35 \%, 1.57 \%$ and $5.46 \%$ for Asteraceae, Cyperaceae and Fabaceae, respectively (Fig. 1). The fact that Fabaceae, which ranked third in richness, accumulated more IV than did Cyperaceae, which ranked second, indicates that relative cover and frequency more accurately describe the importance of each botanical family in the community than do the raw values of richness. Similarly, Rubiaceae and Convolvulaceae, both of which had few taxa in our survey, showed relatively high IVs (Fig. 1). This is due to the fact that the mean frequency of taxa from these families was high in the community studied, as well as to morphological features such as leaf architecture, growth habit and plant size, which directly influence the amount of soil covered by each specimen. The remaining 32 families accumulated only $19.08 \%$ of the overall IV, although they encompassed a total of 75 taxa.

Taxa with an IV $>1.0(n=29)$ accounted for $63.9 \%$ of the total IV. Within this group were taxa defined as forage, inclu- ding five summer grasses (Paspalum notatum, P. indecorum, Mnesithea selloana, Andropogon lateralis, and Axonopus affinis); five winter grasses (Piptochaetium montevidense, P. stipoides, Vulpia bromoides, Briza minor and Danthonia cirrata); one winter legume (Trifolium polymorphum); and one summer legume (Galactia pretiosa). The co-existence of winter and summer forages enhances the potential of the natural grassland as a forage source for livestock production (Nabinger et al. 2009). Still among these taxa, four Asteraceae are worth mentioning (Micropsis spathulata, Soliva pterosperma, Chevreulia sarmentosa and Baccharis coridifolia), since they are especially found at sites with high proportional cover of bare soil and rock. Asteraceae species gain functional benefits from traits such as high seed production and adaptations for wind dispersal, which optimize colonization in such "open" micro-environments.

The four physiognomic patterns of grassland vegetation defined a priori were unevenly represented throughout the 77.3 ha of the sampling area (see methods), and mean percentages of bare soil, rock cover and grass species representativeness were variable among them (Tab. 1). The "open" pattern was characterized by what is locally known as "campos duros" ("hard fields"), with considerable exposure of bare soil, usually accompanied by rock outcrops (Tab. 1), suggesting shallow soil, a condition associated with hilltops and upper hillsides. The "closed" pattern was found mostly in association with the "open" pattern, on hilltops and hillsides, but on apparently deeper soils. Despite the spatial proximity, the two patterns are markedly different regarding the mean proportional cover of bare soil and rocks, and the representativeness of grasses (Tab. 1). The "soft" pattern was mostly found on lower hillsides and in relief depressions near water courses and temporary bodies of water, where the soil is deeper. In this pattern, the mean proportional cover of bare soil is even lower, and the mean IV of grasses is strikingly high (Tab. 1). The "indecorum" pattern comprised SUs in which there was a predominance of Paspalum indecorum and almost no rock outcrops but still lower grass representativeness in comparison with that of the "soft" pattern (Tab. 1). In the "indecorum" pattern, $P$. indecorum is dominant even in the presence of species that dominate in other patterns, such as the grasses Andropogon lateralis and P. notatum, as well as the winter/spring legumes Trifolium polymorphum and Adesmia incana.

Cluster analysis identified two sharp groups among the 90 SUs $(\mathrm{p}>0.1)$. One group comprised all SUs previously included in the "soft" pattern, whereas the other one encompassed SUs included in the "closed" or "open" patterns. There were SUs of the "indecorum" pattern in both groups. In the principal coordinate analysis, the first ordination axis was significant $(\mathrm{p}<0.1)$ and the first two axes trended toward stability, denoting sampling sufficiency for pattern detection (Pillar 1998; 1999a; 1999b). In the resulting scatterplot, all 90 SUs were labeled according to the groups obtained in the cluster analysis (Fig. 2). The SUs 


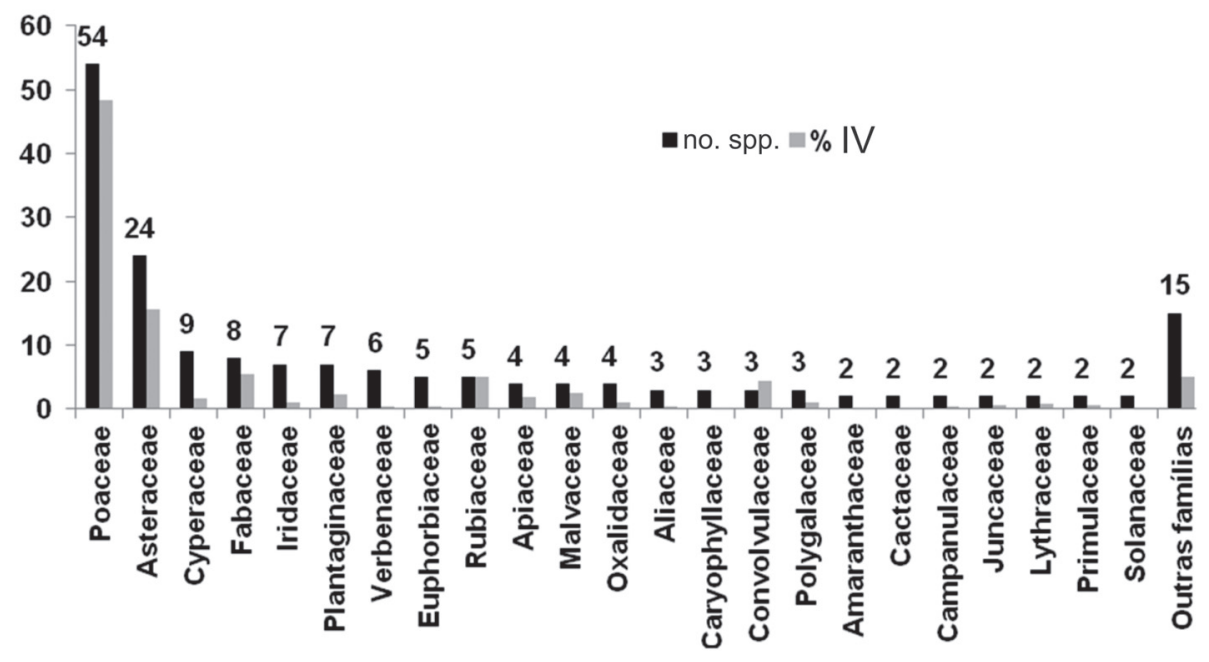

Figure 1. Richness and importance value (IV) of plant families sampled in the structural survey.

Table 1. Proportions of bare soil and rock cover and representativeness of grasses in each a priori physiognomic pattern.

\begin{tabular}{|c|c|c|c|c|c|}
\hline \multirow{2}{*}{ Physiognomic pattern } & \multirow{2}{*}{$\begin{array}{c}\text { Rock cover } \\
\text { (\%) }\end{array}$} & \multirow{2}{*}{$\begin{array}{c}\text { Bare soil } \\
\text { (\%) }\end{array}$} & \multicolumn{3}{|c|}{$\begin{array}{c}\text { Grasses } \\
\text { (accumulated IV) }\end{array}$} \\
\hline & & & Winter & Summer & Total \\
\hline Open & 12.4 & 20.5 & 10 & 25 & 35 \\
\hline Closed & 0.9 & 6.4 & 18 & 26 & 44 \\
\hline Soft & 0.7 & 4.4 & 21 & 40 & 61 \\
\hline Indecorum & 0.3 & 4.9 & 13 & 36 & 49 \\
\hline
\end{tabular}

IV - importance value.

in cluster 1 are closer to each other, reflecting a high level of internal aggregation, whereas those in cluster 2 are more widely scattered, suggesting less internal aggregation. The same scatterplot is presented in Fig. 3 but with SUs labeled according to the a priori physiognomic patterns, as well as the variables with the strongest correlations (i.e., taxa) and the environmental variables bare soil and rock cover. As can be seen, the "soft" SUs on the upper left quadrant are gradually replaced clockwise by "closed" SUs, which in turn are replaced by "open" SUs. This ordination pattern not only reflects the transition between the predetermined physiognomic patterns but also probably reflects a moisture and soil depth gradient, to which grassland vegetation responds by establishing the patchy pattern observed. On the left-hand side of the scatterplot, there are SUs inserted on deeper and more humid soils, which are replaced clockwise by SUs on shallower and drier soils, up to the "open" SUs located at hilltops. The "indecorum" SUs presented no distinguishable pattern in the scatterplot. There are two plausible explanations for this behavior: apart from the marked dominance of Paspalum indecorum, these SUs encompassed plant taxa that were also present in the other patterns; or, unlike those of the other patterns, "indecorum" SUs were not associated with a specific topology. The latter argument suggests that the dominance of $P$. indecorum in some vegetation patches is independent of the observed moisture/soil depth gradient and must result from unobserved biotic/abiotic variables or naturally clumped population distribution. Paspalum indecorum is a relatively rare species, which is cited here for the first time in an ecological survey conducted in southern Brazil. It shows striking biological similarities to $P$. notatum, a widespread and typically dominant grass species. Apparently, the two species play similar functional roles, although why they alternately dominate vegetation patches, even at a local scale, is an unanswered question that merits further investigation.

The distribution of variables best correlated with the ordination axes (Fig. 3) corroborates the idea that there is a moisture/soil depth gradient in the study area. Andropogon lateralis, Vulpia bromoides and Steinchisma hians, clustered near "soft" SUs, are species usually associated with deeper soils and more humid conditions, and the last two are C3 grasses. According to Lezama et al. (2010), this vegetation pattern constitutes "meso-hydrophytic grazing lands" in Uruguay, usually found in plain-concave portions of the terrain, with similar cover of winter and summer grasses. In our survey, however, the summer/winter grass ratio was 2:1 in the "soft" pattern. This might be explained by the 


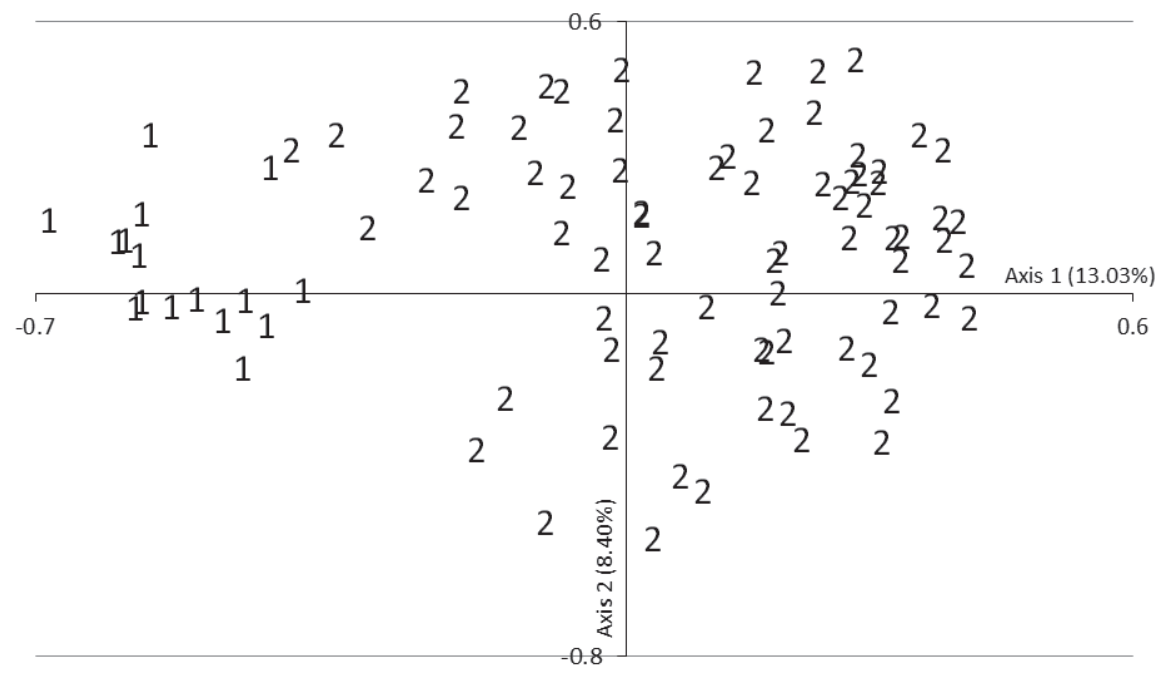

Figure 2. Scatterplot obtained in the principal coordinate analysis of 90 sampling units (SUs) described by 178 plant taxa. SUs are labeled according to sharp groups resulting from a cluster analysis.

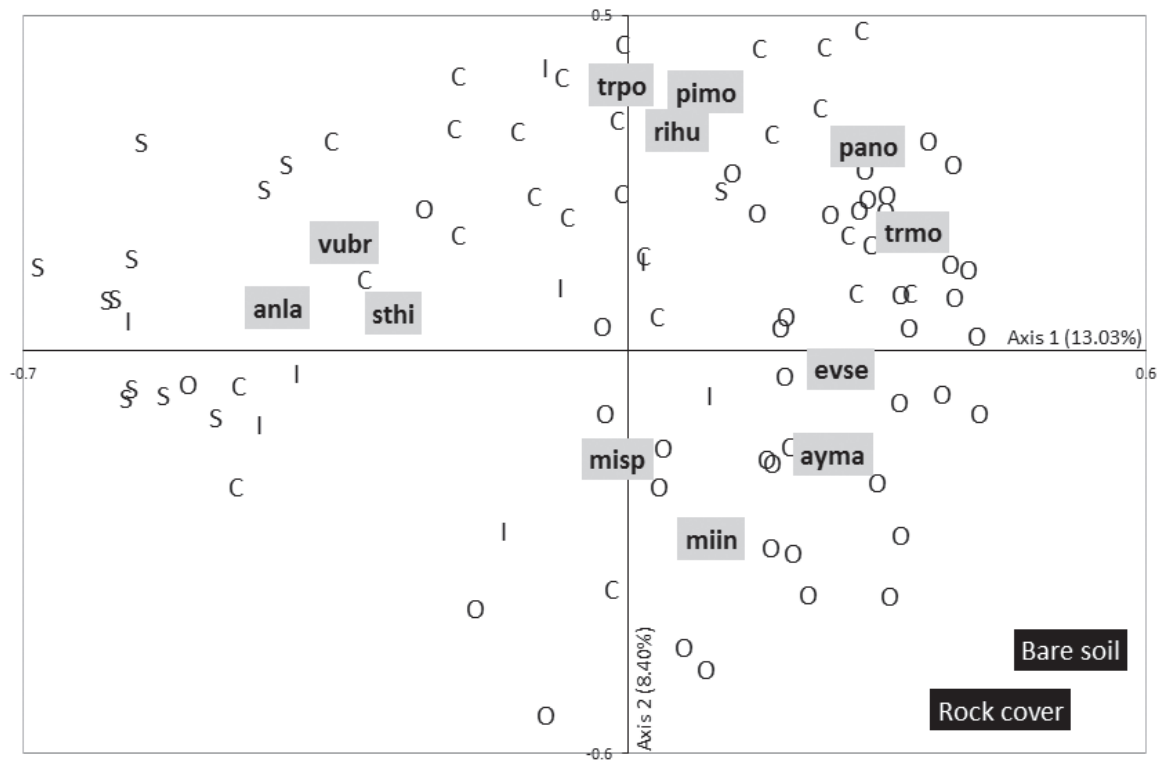

Figure 3. Scatterplot obtained in the principal coordinate analysis of 90 sampling units (SUs) described by 178 plant taxa. SUs are labeled according to the four physiognomic patterns defined a priori. Taxa that best correlated with ordination axes and abiotic variables were also plotted.

S - "soft"; C - "closed"; O - "open"; I - "indecorum"; ayma - Ayenia mansfeldiana; evse - Evolvolus sericeus; miin - Microchloa indica; misp - Micropsis spathulata; pano - Paspalum notatum; pimo - Piptochaetium montevidense; rihu - Richardia humistrata; sthi - Steinchisma hians; trmo - Trachypogon montufarii; trpo - Trifolium polymorphum; vubr - Vulpia bromoides.

geographic position of southern Brazilian grasslands, which are farther north than are the Uruguayan grasslands and, consequently, encompass more tropical summer grasses (Boldrini \& Longhi-Wagner 2011).

The "closed" pattern was characterized by Paspalum notatum, Piptochaetium montevidense, Richardia humistrata and Trifolium polymorphum (Fig. 3). The first three species are common in natural grasslands throughout southern Brazil (Overbeck et al. 2007), as well as in central Uruguay, especially in grazed areas (Altesor et al. 2005), and have bro- ad ecological amplitude, thriving under variable conditions, whereas T. polymorphum is a pampas species restricted to southernmost Brazil, Uruguay, Argentina and Paraguay, typically found in moderately drained soils.

The "open" SUs were characterized by the presence of Microchloa indica, Evolvulus sericeus, Ayenia mansfeldiana, Micropsis spathulata and Trachypogon montufarii var. montufarii (Fig. 3). All of those species are typically found in open grasslands throughout South America. In Uruguay, this vegetation is referred to as "lithophytic steppe" and is 
characterized by higher cover of summer species than winter species, usually in high relief positions (Lezama et al. 2010). Therefore, our "open" pattern seems to be analogous to this Uruguayan physiognomy, once again providing evidence that supports the classification of South American natural subtropical grasslands as a discrete ecological unit (Ferreira \& Boldrini 2011). The gradual substitution of SUs belonging to different patterns and of taxa along the gradient explains why our cluster analysis identified only two well-defined groups.

The variables "bare soil" and "rock cover" were strongly correlated with the ordination axes (Fig. 3). Correlation values were positive for axis 1 and negative for axis 2 , so that both variables were plotted towards the "open" (or "well-drained", considering moisture) extremity of the observed gradient. These high correlation values strengthen the interpretation of the observed pattern as a moisture/soil depth gradient. Alternatively, the high correlation values could be interpreted as evidence of a "community openness" gradient, although the two interpretations are not mutually exclusive.

Natural grasslands on basalt-derived Litholic Neosols show high floristic richness and plant diversity, similar to those found at other sites throughout southern Brazil but with greater representation of winter forage species. The presence and local dominance of Paspalum indecorum, a species scarcely found in other grassland communities, are also worth mentioning.

We detected an apparently natural structural variability in the vegetation, resulting in patterns that probably arose in function of soil conditions. These patterns match vegetation physiognomies described for Uruguayan grasslands, providing further evidence of an ecological unit comprising South American subtropical grasslands.

Finally, bare soil and rock cover represent a significant area in grasslands growing on Litholic Neosols. Because livestock farming is one of the most important economic activities in the Pampa biome, these variables should be considered when estimating forage availability per area on lands where this soil type is represented in the landscape.

\section{Acknowledgement}

We thank the Jiménez family for allowing this study to be carried out on the Santo Antônio Farm and for providing the necessary infrastructure. Financial support was provided by the Brazilian Coordenação de Aperfeiçoamento de Pessoal de Nivel Superior (CAPES, Office for the Advancement of Higher Education; scholarship to MFP).

\section{References}

Altesor, A.; Oesterheld. M; Leoni, E.; Lezama, F. \& Rodríguez, C. 2005. Effect of grazing exclosure on community structure and productivity of a Uruguayan grassland. Plant Ecology 179: 83-91.
Barros, M. 1960. Las Ciperaceas del Estado de Santa Catalina. Sellowia 12: $181-448$.

Berretta, E.J. 1998. Principales características climáticas y edáficas de la región de Basalto en Uruguay. In: Seminario de actualización en tecnologías para basalto. Tacuarembó. Montevideo, INIA Serie técnica.

Bilenca, D.N. \& Miñarro, F.O. 2004. Áreas valiosas de pastizal en las pampas y campos de Argentina, Uruguay y sur de Brasil. Buenos Aires, Fundación Vida Silvestre Argentina.

Boldrini, I.I.; Trevisan, R. \& Schneider, A.A. 2008. Estudo florístico e fitossociológico de uma área às margens da lagoa do Armazém, Osório, Rio Grande do Sul, Brasil. Revista Brasileira de Biociências 6(4): 355-367.

Boldrini, I.I. \& Longhi-Wagner, H.M. 2011. Poaceae no Rio Grande do Sul, diversidade, importância na fitofisionomia e conservação. Ciência \& Ambiente 42: 71-92.

Burkart, A. \& Bacigalupo, N.M. (Eds.). 2005. Flora Ilustrada de Entre Ríos (Argentina) Parte IV: Dicotiledóneas Arquiclamídeas, B: Geraniales a Umbelliflorales. Tomo 6. Buenos Aires, Colección Cientifica del INTA.

Burkart, A. (Ed.). 1969. Flora Ilustrada de Entre Ríos (Argentina) Parte II: Monocotiledóneas: Gramíneas. Tomo 6. Buenos Aires, Colección Cientifica del INTA.

Burkart, A. (Ed.). 1974. Flora Ilustrada de Entre Ríos (Argentina) Parte VI: Dicotiledoneas Metaclamídeas, B: Rubiales, Cucurbitales, Campanulales (incluso Compuestas). Tomo 6. Buenos Aires, Colección Cientifica del INTA.

Burkart, A. (Ed.). 1979. Flora Ilustrada de Entre Ríos (Argentina) Parte V: Dicotiledóneas Metaclamídeas, A: Primulales a Plantaginales. Tomo 5 y 6. Buenos Aires, Colección Cientifica del INTA.

Burkart, A. (Ed.). 1987. Flora Ilustrada de Entre Ríos (Argentina) Parte III: Dicotiledóneas Arquiclamídeas, A: Salicales a Rosales (incluso Leguminosas). Tomo 6. Buenos Aires, Colección Cientifica del INTA.

Delprete, P.G.; Smith, L.B. \& Klein, R.M. 2004. Rubiáceas Pp. 1-344. In Reitz, R. \& Reis, A. (Eds.). Flora ilustrada catarinense. Vol. 1. Itajaí, Herbário Barbosa Rodrigues.

Delprete, P.G.; Smith, L.B. \& Klein, R.M. 2005. Rubiáceas Pp. 349-842. In: Reitz, R. \& Reis, A. (Eds.). Flora ilustrada catarinense. Vol. 2. Itajaí, Herbário Barbosa Rodrigues.

EMBRAPA, 1999. Sistema brasileiro de classificação de solos. Brasília, EMBRAPA.

Ferreira, P.M.A. \& Boldrini, I.I. 2011. Potential Reflection of Distinct Ecological Units in Plant Endemism Categories. Conservation Biology 25: 672-679.

Ferreira, P.M.A. \& Setubal, R.B. 2009. Florística e fitossociologia de um campo natural no município de Santo Antônio da Patrulha, Rio Grande do Sul, Brasil. Revista Brasileira de Biociências 7(2): 195-204.

Ferreira, P.M.A.; Müller, S.C.; Boldrini, I.I. \& Eggers, L. 2010. Floristic and vegetation structure of a granitic grassland in Southern Brazil. Revista Brasileira de Botânica 33: 21-36.

Guterres D.B.; Bayer C.; Castilhos Z.M.S.; Nabinger C. 2006. Carbono orgânico em chernossolo sob pastagem nativa do RS. In: Anais da $16^{\mathrm{a}}$ Reunião brasileira de manejo e conservação do solo e da água. Aracaju, UFSE/SBCS.

Hasenack, H.; Weber, E.J.; Boldrini, I.I. \& Trevisan, R. 2010. Mapa de sistemas ecológicos da ecorregião das savanas uruguaias em escala 1:500.000 ou superior e relatório técnico descrevendo insumos utilizados e metodologia de elaboração do mapa de sistemas ecológicos. Porto Alegre, UFRGS, Centro de Ecologia.

Hodgson, J. 1990. Grazing management: science into practice. Harlow. Longman Scientific \& Technical.

Leivas, J.F.; Berlato, M.A. \& Fontana, D.C. 2006. Risco de deficiência hídrica decendial na metade sul do Estado do Rio Grande do Sul. Revista Brasileira de Engenharia Agrícola e Ambiental 10(2): 397-407.

Lezama, F.; Altesor, A.; Leon, R.J. \& Paruelo, J.M. 2006. Heterogeneidad de la vegetación en pastizales naturales de región basáltica de Uruguay. Ecología Austral 16: 167-182.

Lezama, F.; Altesor, A.; Pereira, M. \& Paruelo, J.M. 2010. Descripción de la heterogeneidad florística de las principales regiones geomorfológicas de Uruguay. p. 15-32. In: Altesor, A.; Ayala, W.; Paruelo, J. M. Bases ecológicas y tecnológicas para el manejo de pastizales., Uruguay, 2010. INIA (Serie FPTA, 26). 
Londo, G. 1976. The decimal scale for releves of permanent quadrats. Vegetatio 33(1): 61-64.

Lourteig, A. 1983. Oxalidáceas. In: Reitz, R. (Ed.). Flora ilustrada catarinense. Itajaí, Herbário Barbosa Rodrigues.

Magurran, A.E. 1988. Ecological diversity and its measurement. Princeton, Princeton University Press.

Matteucci, S.D. \& Colma, A. 1982. Metodología para el estudio de la vegetación. Washington. The General Secretariat of the Organization of American States.

Müeller-Dombois, D. \& Ellenberg, H. 1974. Aims and methods of vegetation ecology. New York, John Wiley.

Nabinger, C.; Ferreira, E.T.; Freitas, A.K.; Carvalho, P.C.F. \& Sant'anna, D.M. 2009. Produção animal com base no campo nativo: aplicações de resultados de pesquisa. Pp.175-198. In: Pillar, V.P.; Muller, S.C.; Castilhos, Z.M.S.; Jacques, A.V.A. (Eds). Campos sulinos: conservação e uso sustentável. Brasília 2009. MMA.

Orlóci, L. 1967. An agglomerative method for classification of plant communities. Journal of Ecology 55: 195-205.

Overbeck G.E.; Müller S.C.; Fidelis A.; Pfadenhauer J.; Pillar V.D.; Blanco C.C.; Boldrini I.I.; Both R. \& Forneck E.D. 2007. Brazil's neglected biome: the South Brazilian Campos. Perspectives in Plant Ecology, Evolution and Systematics 9: 101-116.

Pielou, E.C. 1969. An introduction to mathematical ecology. New York, Wiley-Interscience.

Pillar, V.D. 1997. Multivariate exploratory analysis and randomization testing with MULTIV. Coenoses 12: 145-148.
Pillar, V.D. 1998. Sampling sufficiency in ecological surveys. Abstracta Botanica 22: 37-48.

Pillar V.D. 1999a. How sharp are classifications? Ecology 80(8): 2508-2516.

Pillar, V.D. 1999b. The bootstrapped ordination reexamined. Journal of Vegetation Science 10: 895-902.

Rosengurtt, B. 1979. Tablas de comportamiento de las especies de plantas de campos naturales en el Uruguay. Montevideo, Universidad de la República, Facultad de Agronomía.

Rosengurtt, B., De Maffei, B.A. \& De Artucio, P.I. 1970. Gramíneas Uruguayas. Montevideo, Dep. Publ. Univ. de la Republica.

Soares, A.B.; Carvalho, P.C.F.; Nabinger, C.A.; Semmelmann, C.; Trindade, J.K.; Freitas, T.S.; Pinto, K.S.; Fontoura Júnior, J.A. \& Frizzo, A. 2005. Produção animal e de forragem em uma pastagem nativa submetida a distintas ofertas de forragem. Ciência Rural 35(5): 1148-1154.

Stammel, J.G. 1996. Desenvolvimento sustentável do Pampa. Pp. 325 333. In: Alvarez, V.H.; Fontes, M.P.F. O solo nos grandes domínios morfoclimáticos do Brasil e o desenvolvimento sustentado. Viçosa, UFV.

Tornquist, C.G. \& Bayer, C. 2009. Serviços ambientais: oportunidades para a conservação dos Campos Sulinos. Pp. 122-127. In: Pillar, V.P.; Muller, S.C.; Castilhos, Z.M.S..; Jacques, A.V.A. (Eds). Campos sulinos: conservação e uso sustentável. Brasília, MMA.

Ward, J.H. 1963. Hierarchical grouping to optimize an objective function. Journal of the American Statistical Association 58: 236-244. 
Appendix 1. Floristic list obtained for the natural grassland in the municipality of Santana do Livramento, Brazil.

\begin{tabular}{|c|c|}
\hline Family & Species/Subspecies/Variety \\
\hline Acanthaceae & Stenandrium dulce (Cav.) Nees \\
\hline Alliaceae & Ipheion sessile (Phil.) Traub* \\
\hline Alliaceae & Nothoscordum bonariense (Pers.) Beauverd \\
\hline Alliaceae & Nothoscordum gaudichaudianum Kunth \\
\hline Alliaceae & Nothoscordum montevidense Beauverd \\
\hline Amaranthaceae & Chenopodium haumanii Ulbr.* \\
\hline Amaranthaceae & Gomphrena celosioides Mart. \\
\hline Amaranthaceae & Pfaffia gnaphaloides (L. f.) Mart.* \\
\hline Amaranthaceae & Pfaffia tuberosa Hicken \\
\hline Amaryllidaceae & Zephyranthes mesochloa Herb. ex Lindl. \\
\hline Amaryllidaceae & Habranthus tubispathus (L'Hér.) Traub \\
\hline Apiaceae & Ammoselinum rosengurtii Mathias \& Constance \\
\hline Apiaceae & Apium leptophyllum (Pers.) F. Muell. ex Benth. \\
\hline Apiaceae & Eryngium echinatum Urb. \\
\hline Apiaceae & Eryngium horridum Malme* \\
\hline Apiaceae & Eryngium nudicaule Lam. \\
\hline Apocynaceae & Oxypetalum microphyllum Hook. \& Arn. \\
\hline Araliaceae & Hydrocotyle exigua Malme \\
\hline Asteraceae & Acmella bellidioides (Sm.) R.K.Jansen \\
\hline Asteraceae & Aspilia montevidensis (Spreng.) Kuntze \\
\hline Asteraceae & Aster squamatus (Spreng.) Hieron. \\
\hline Asteraceae & Baccharis coridifolia DC. \\
\hline Asteraceae & Chaptalia piloselloides (Vahl) Baker \\
\hline Asteraceae & Chaptalia runcinata Kunth \\
\hline Asteraceae & Chaptalia sinuata (Less.) Baker \\
\hline Asteraceae & Chevreulia acuminata Less. \\
\hline Asteraceae & Chevreulia sarmentosa (Pers.) S.F.Blake \\
\hline Asteraceae & Conyza monorchis (Griseb.) Cabrera \\
\hline Asteraceae & Conyza primulifolia (Lam.) Cuatrec. \& Lourteig* \\
\hline Asteraceae & Elephantopus mollis Kunth \\
\hline Asteraceae & Facelis retusa (Lam.) Sch.Bip. \\
\hline Asteraceae & Gamochaeta americana (Mill.) Wedd. \\
\hline Asteraceae & Gamochaeta coarctata (Willd.) Kerguélen \\
\hline Asteraceae & Gamochaeta falcata (Lam.) Cabrera \\
\hline Asteraceae & Hypochaeris variegata (Lam.) Baker \\
\hline Asteraceae & Micropsis spathulata (Pers.) Cabrera \\
\hline Asteraceae & Pamphalea bupleurifolia Less. $^{*}$ \\
\hline Asteraceae & Pamphalea heterophylla Less. \\
\hline Asteraceae & Perezia multiflora ssp. sonchifolia (Baker) Vuilleum. \\
\hline Asteraceae & Porophyllum linifolium (Ard.) DC. \\
\hline Asteraceae & Pterocaulon alopecuroides (Lam.) DC. \\
\hline
\end{tabular}


Marcelo Fett Pinto, Carlos Nabinger, Ilsi Iob Boldrini, Pedro Maria de Abreu Ferreira,

Robberson Bernal Setubal, Rafael Trevisan, Jean Kássio Fedrigo and Igor Justin Carassai

Appendix 1. Continuation.

\begin{tabular}{|c|c|}
\hline Family & Species/Subspecies/Variety \\
\hline Asteraceae & Soliva pterosperma (Juss.) Less. \\
\hline Asteraceae & Sommerfeltia spinulosa (Spreng.) Less. \\
\hline Asteraceae & Stenachaenium campestre Baker \\
\hline Asteraceae & Lessingianthus sellowii (Less.) H. Rob.* \\
\hline Asteraceae & Vernonia sp. ${ }^{\star}$ \\
\hline Brassicaceae & Lepidium aletes J.F. Macbr. \\
\hline Cactaceae & Gymnocalycium uruguayense (Arechav.) Britton \& Rose \\
\hline Cactaceae & Parodia mammulosa (Lem.) N.P. Taylor \\
\hline Campanulaceae & Triodanis biflora (Ruiz \& Pav.) Greene \\
\hline Campanulaceae & Wahlenbergia linarioides (Lam.) A. DC. \\
\hline Caryophyllaceae & Cerastium commersonianum DC. \\
\hline Caryophyllaceae & Cerastium glomeratum Thuill. \\
\hline Caryophyllaceae & Paronychia chilensis DC. \\
\hline Caryophyllaceae & Polycarpon tetraphyllum (L.) L.* \\
\hline Cistaceae & Helianthemum brasiliense (Lam.) Pers. \\
\hline Commelinaceae & Tradescantia umbraculifera Hand.-Mazz. \\
\hline Convolvulaceae & Convolvulus laciniatus Desr. \\
\hline Convolvulaceae & Dichondra sericea $\mathrm{Sw}$. \\
\hline Convolvulaceae & Evolvulus sericeus Sw. \\
\hline Crassulaceae & Crassula longipes (Rose) M. Bywater \& Wickens ${ }^{*}$ \\
\hline Cyperaceae & Abildgaardia ovata (Burm. f.) Kral \\
\hline Cyperaceae & Bulbostylis capillaris (L.) Kunth ex C.B. Clarke \\
\hline Cyperaceae & Carex bonariensis Desf. ex Poir. \\
\hline Cyperaceae & Carex phalaroides Kunth \\
\hline Cyperaceae & Carex sororia Kunth \\
\hline Cyperaceae & Cyperus reflexus Vahl \\
\hline Cyperaceae & Eleocharis bonariensis Nees $^{*}$ \\
\hline Cyperaceae & Eleocharis dunensis Kük. \\
\hline Cyperaceae & Eleocharis montana (Kunth) Roem. \& Schult.* \\
\hline Cyperaceae & Eleocharis sellowiana Kunth \\
\hline Cyperaceae & Eleocharis viridans Kük. ex Osten \\
\hline Cyperaceae & Rhynchospora scutellata Griseb.* \\
\hline Euphorbiaceae & Euphorbia selloi (Klotzsch \& Garcke) Boiss. \\
\hline Euphorbiaceae & Euphorbia sp. \\
\hline Euphorbiaceae & Euphorbia spathulata Lam. \\
\hline Euphorbiaceae & Euphorbia stenophylla Boiss. \\
\hline Euphorbiaceae & Tragia geraniifolia Klotzsch ex Baill. \\
\hline Fabaceae & Adesmia bicolor (Poir.) DC.* \\
\hline Fabaceae & Adesmia incana Vogel \\
\hline Fabaceae & Desmodium incanum DC.* \\
\hline Fabaceae & Galactia pretiosa Burkart \\
\hline
\end{tabular}


Appendix 1. Continuation.

\begin{tabular}{|c|c|}
\hline Family & Species/Subspecies/Variety \\
\hline Fabaceae & Macroptilium psammodes (Lindm.) S. I. Drewes \& R. A. Palácios \\
\hline Fabaceae & Macroptilium prostratum (Benth.) Urb. \\
\hline Fabaceae & Mimosa adpressa Hook. \& Arn.* \\
\hline Fabaceae & Mimosa amphigena Burkart* \\
\hline Fabaceae & Mimosa burkartii Marchesi* \\
\hline Fabaceae & Mimosa cruenta Benth.* \\
\hline Fabaceae & Mimosa flagellaris Benth.* \\
\hline Fabaceae & Rhynchosia diversifolia M. Mich. var. diversifolia \\
\hline Fabaceae & Rhynchosia senna Gillies ex Hook. \\
\hline Fabaceae & Senna nana (Benth.) H.S. Irwin \& Barneby* \\
\hline Fabaceae & Stylosanthes montevidensis Vogel \\
\hline Fabaceae & Trifolium polymorphum Poir. \\
\hline Herreriaceae & Herreria montevidensis Klotzsch ex Griseb. \\
\hline Iridaceae & Calydorea nuda Baker \\
\hline Iridaceae & Cypella herbertii Hook. \\
\hline Iridaceae & Herbertia lahue (Molina) Goldblatt \\
\hline Iridaceae & Herbertia sp. * \\
\hline Iridaceae & Sisyrinchium micranthum Cav. \\
\hline Iridaceae & Sisyrinchium minutiflorum Klatt \\
\hline Iridaceae & Sisyrinchium pachyrhizum Baker \\
\hline Iridaceae & Sisyrinchium scariosum I.M. Johnst. \\
\hline Juncaceae & Juncus biflorus Elliott ${ }^{*}$ \\
\hline Juncaceae & Juncus capillaceus Lam. \\
\hline Juncaceae & Juncus dichotomus Elliott* \\
\hline Juncaceae & Juncus imbricatus Laharpe ${ }^{*}$ \\
\hline Juncaceae & Juncus microcephalus Kunth \\
\hline Juncaceae & Juncus sellowianus Kunth* \\
\hline Lamiaceae & Scutellaria racemosa Pers. \\
\hline Linaceae & Cliococca selaginoides (Lam.) C.M. Rogers \& Mildner \\
\hline Linaceae & Linum carneum A. St.-Hil.* \\
\hline Linaceae & Linum erigeroides A. St.-Hil.* \\
\hline Lythraceae & Cuphea carthagenensis (Jacq.) J.F. Macbr. \\
\hline Lythraceae & Cuphea glutinosa Cham. \& Schltdl. \\
\hline Malvaceae & Ayenia mansfeldiana (Herter) Herter ex Cristóbal \\
\hline Malvaceae & Krapovickasia flavescens (Cav.) Fryxell \\
\hline Malvaceae & Modiolastrum malvifolium (Griseb.) K. Schum.* \\
\hline Malvaceae & Pavonia glechomoides A. St.-Hil. \\
\hline Malvaceae & Pavonia hastata Cav. \\
\hline Malvaceae & Sida dubia Saint-Hilaire* \\
\hline Moraceae & Dorstenia brasiliensis Lam. \\
\hline Onagraceae & Oenothera mollissima L. $^{*}$ \\
\hline
\end{tabular}


Marcelo Fett Pinto, Carlos Nabinger, Ilsi Iob Boldrini, Pedro Maria de Abreu Ferreira,

Robberson Bernal Setubal, Rafael Trevisan, Jean Kássio Fedrigo and Igor Justin Carassai

Appendix 1. Continuation.

\begin{tabular}{|c|c|}
\hline Family & Species/Subspecies/Variety \\
\hline Onagraceae & Oenothera parodiana Munz \\
\hline Orchidaceae & Habenaria parviflora Lindl. \\
\hline Orobanchaceae & Agalinis communis (Cham. \& Schltdl.) D’Arcy \\
\hline Oxalidaceae & Oxalis bipartita A.St.-Hil. subsp. bipartita \\
\hline Oxalidaceae & Oxalis eriocarpa DC. \\
\hline Oxalidaceae & Oxalis lasiopetala Zucc. \\
\hline Oxalidaceae & Oxalis sp. \\
\hline Plantaginaceae & Angelonia integerrima Spreng. \\
\hline Plantaginaceae & Gratiola peruviana $\mathrm{L}$. \\
\hline Plantaginaceae & Mecardonia flagellaris (Cham. \& Schlecht.) Rossow subsp.flagellaris * \\
\hline Plantaginaceae & Mecardonia tenella (Cham. \& Schltdl.) Pennell \\
\hline Plantaginaceae & Plantago brasiliensis Sims \\
\hline Plantaginaceae & Plantago myosuros Lam. \\
\hline Plantaginaceae & Scoparia montevidensis (Spreng.) R.E. Fr. \\
\hline Plantaginaceae & Veronica peregrina $\mathrm{L}$. \\
\hline Poaceae & Agrostis hygrometrica Nees \\
\hline Poaceae & Agrostis tandilensis (Kuntze) Parodi \\
\hline Poaceae & Andropogon lateralis Nees \\
\hline Poaceae & Andropogon ternatus (Spreng.) Nees \\
\hline Poaceae & Aristida echinulata Roseng. \& Izag. \\
\hline Poaceae & Aristida murina Cav. \\
\hline Poaceae & Aristida venustula Arechav. var. venustula \\
\hline Poaceae & Axonopus affinis Chase \\
\hline Poaceae & Bothriochloa laguroides (DC.) Herter var. laguroides \\
\hline Poaceae & Bouteloua megapotamica (Spreng.) Kuntze \\
\hline Poaceae & Briza minor $\mathrm{L}$. \\
\hline Poaceae & Chascolytrum poomorphum (J. Presl) Essi, Longhi- Wagner \& Souza-Chies \\
\hline Poaceae & Chascolytrum rufum J.Presl \\
\hline Poaceae & Chascolytrum subaristatum (Lam.) Desv. \\
\hline Poaceae & Calamagrostis viridiflavescens (Poir.) Steud. var. viridiflavescens \\
\hline Poaceae & Chloris grandiflora Roseng. \& Izag. \\
\hline Poaceae & Mnesithea selloana (Hack.) de Koning \& Sosef \\
\hline Poaceae & Cynodon dactylon (L.) Pers. var. dactylon \\
\hline Poaceae & Danthonia cirrata Hack. \& Arechav. \\
\hline Poaceae & Danthonia montevidensis Hack. \& Arechav. \\
\hline Poaceae & Dichanthelium sabulorum (Lam.) Gould \& C.A. Clark var. sabulorum \\
\hline Poaceae & Eragrostis bahiensis Schrad. ex Schult. \\
\hline Poaceae & Eragrostis lugens Nees \\
\hline Poaceae & Eragrostis neesii Trin. var. neesii \\
\hline Poaceae & Eustachys brevipila (Roseng. \& Izag.) Caro \& E.A. Sánchez \\
\hline Poaceae & Hordeum euclaston Steud. \\
\hline
\end{tabular}


Appendix 1. Continuation.

\begin{tabular}{|c|c|}
\hline Family & Species/Subspecies/Variety \\
\hline Poaceae & Luziola peruviana Juss. ex J.F. Gmel.* \\
\hline Poaceae & Melica brasiliana Ard. \\
\hline Poaceae & Melica rigida Cav. \\
\hline Poaceae & Microchloa indica (L. f.) P. Beauv. \\
\hline Poaceae & Paspalum dilatatum Poir. \\
\hline Poaceae & Paspalum indecorum $\mathrm{Mez}$ \\
\hline Poaceae & Paspalum lepton Schult. \\
\hline Poaceae & Paspalum notatum Alain ex Flüggé \\
\hline Poaceae & Paspalum plicatulum Michx. \\
\hline Poaceae & Paspalum pumilum Nees \\
\hline Poaceae & Paspalum urvillei Steud. \\
\hline Poaceae & Phalaris angusta Nees ex Trin. \\
\hline Poaceae & Piptochaetium bicolor (Vahl) E. Desv. var. bicolor \\
\hline Poaceae & Piptochaetium lasianthum Griseb.* \\
\hline Poaceae & Piptochaetium montevidense (Spreng.) Parodi \\
\hline Poaceae & Piptochaetium ruprechtianum E. Desv.* \\
\hline Poaceae & Piptochaetium stipoides (Trin. \& Rupr.) Hack. var. stipoides \\
\hline Poaceae & Piptochaetium stipoides var. chaetophorum (Griseb.) Parodi \\
\hline Poaceae & Poa aпnиа $\mathrm{L}$. \\
\hline Poaceae & Poa lanigera Nees \\
\hline Poaceae & Polypogon chilensis (Kunth) Pilg.* \\
\hline Poaceae & Polypogon elongatus Lag.* \\
\hline Poaceae & Schizachyrium imberbe (Hack.) A. Camus \\
\hline Poaceae & Schizachyrium spicatum (Spreng.) Herter \\
\hline Poaceae & Setaria parviflora (Poir.) Kerguélen \\
\hline Poaceae & Setaria vaginata Spreng. var. vaginata \\
\hline Poaceae & Sporobolus indicus (L.) R. Br. \\
\hline Poaceae & Steinchisma hians (Elliott) Nash \\
\hline Poaceae & Stipa charruana Arechav.* \\
\hline Poaceae & Stipa setigera C. Presl var. setigera \\
\hline Poaceae & Trachypogon montufarii (Kunth) Nees var. montufarii \\
\hline Poaceae & Trachypogon montufarii var. mollis (Nees) Andersson \\
\hline Poaceae & Tridens hackelii (Arechav.) Parodi \\
\hline Poaceae & Tripogon spicatus (Nees) Ekman \\
\hline Poaceae & Vulpia bromoides (L.) Gray \\
\hline Polygalaceae & Monnina resedoides A. St.-Hil.* \\
\hline Polygalaceae & Polygala bonariensis Grondona \\
\hline Polygalaceae & Polygala duarteana A. St.-Hil. \& Moq.* \\
\hline Polygalaceae & Polygala molluginifolia A. St.-Hil. \& Moq. \\
\hline Polygalaceae & Polygala pulchella A. St.-Hil. \& Moq. \\
\hline Polygonaceae & Polygonum punctatum Buch.-Ham. ex D. Don* \\
\hline
\end{tabular}


Marcelo Fett Pinto, Carlos Nabinger, Ilsi Iob Boldrini, Pedro Maria de Abreu Ferreira,

Robberson Bernal Setubal, Rafael Trevisan, Jean Kássio Fedrigo and Igor Justin Carassai

Appendix 1. Continuation.

\begin{tabular}{|c|c|}
\hline Family & Species/Subspecies/Variety \\
\hline Polygonaceae & Rumex cuneifolius Campd.* \\
\hline Primulaceae & Anagallis minima (L.) E.H.L. Krause \\
\hline Primulaceae & Pelletiera serpyllifolia (Schreb.) Kuntze \\
\hline Rubiaceae & Galium hirtum Lam.* \\
\hline Rubiaceae & Galium richardianum (Gillies ex Hook. \& Arn.) Endl. ex Walp. \\
\hline Rubiaceae & Richardia humistrata (Cham. \& Schltdl.) Steud. \\
\hline Rubiaceae & Richardia stellaris (Cham. \& Schltdl.) Steud. \\
\hline Rubiaceae & Spermacoce brachystemonoides (Cham. \& Schltdl.) Kuntze* \\
\hline Rubiaceae & Spermacoce capitata Ruiz \& Pav. \\
\hline Rubiaceae & Spermacoce verticillata $\mathrm{L}$. \\
\hline Solanaceae & Bouchetia anomala (Miers) Britton \& Rusby* \\
\hline Solanaceae & Calibrachoa humilis (Fries) Stehmann \& Semir ${ }^{*}$ \\
\hline Solanaceae & Calibrachoa ovalifolia (Miers) Stehmann \& Semir \\
\hline Solanaceae & Nicotiana bonariensis Lehm. \\
\hline Turneraceae & Turnera sidoides subsp. integrifolia (Griseb.) Arbo \\
\hline Verbenaceae & Glandularia nana (Moldenke) Tronc. \\
\hline Verbenaceae & Glandularia peruviana (L.) Small ${ }^{\star}$ \\
\hline Verbenaceae & Glandularia subincana Tronc. \\
\hline Verbenaceae & Glandularia tenera (Spreng.) Cabrera \\
\hline Verbenaceae & Lippia villafloridana Kuntze \\
\hline Verbenaceae & Verbena filicaulis Schauer* \\
\hline Verbenaceae & Verbena gracilescens (Cham.) Herter \\
\hline Verbenaceae & Verbena montevidensis Spreng. \\
\hline Violaceae & Hybanthus parviflorus (L. f.) Baill. \\
\hline
\end{tabular}

${ }^{\star}$ Found only in the floristic survey; the remaining taxa were found in sampling units from the structural survey. 
Appendix 2. Plant taxa found in the vegetation structural survey in 90 sampling units, with respective absolute and relative frequency and cover (AF, RF, AC and $\mathrm{RC}$, respectively).

\begin{tabular}{|c|c|c|c|c|c|}
\hline Family & Species/Subspecies/Variety & AF & $\begin{array}{l}\text { RF } \\
(\%)\end{array}$ & AC & $\begin{array}{l}\text { RC } \\
(\%)\end{array}$ \\
\hline Acanthaceae & Stenandrium dulce & 55 & 2.788 & 193 & 1.545 \\
\hline Alliaceae & Nothoscordum bonariense & 1 & 0.051 & 2 & 0.016 \\
\hline Alliaceae & Nothoscordum gaudichaudianum & 3 & 0.152 & 3 & 0.024 \\
\hline Alliaceae & Nothoscordum montevidense & 5 & 0.253 & 7 & 0.056 \\
\hline Amaranthaceae & Gomphrena celosioides & 4 & 0.203 & 7 & 0.056 \\
\hline Amaranthaceae & Pfaffia tuberosa & 1 & 0.051 & 1 & 0.008 \\
\hline Apiaceae & Ammoselinum rosengurtii & 9 & 0.456 & 19 & 0.152 \\
\hline Apiaceae & Apium leptophyllum & 21 & 1.064 & 43 & 0.344 \\
\hline Apiaceae & Eryngium echinatum & 1 & 0.051 & 2 & 0.016 \\
\hline Apiaceae & Eryngium nudicaule & 15 & 0.760 & 72 & 0.576 \\
\hline Apocynaceae & Oxypetalum microphyllum & 2 & 0.101 & 8 & 0.064 \\
\hline Araliaceae & Hydrocotyle exigua & 10 & 0.507 & 16 & 0.128 \\
\hline Asteraceae & Acmella bellidioides & 10 & 0.507 & 45 & 0.360 \\
\hline Asteraceae & Aspilia montevidensis & 3 & 0.152 & 7 & 0.056 \\
\hline Asteraceae & Aster squamatus & 2 & 0.101 & 5 & 0.040 \\
\hline Asteraceae & Baccharis coridifolia & 14 & 0.710 & 187 & 1.497 \\
\hline Asteraceae & Chaptalia piloselloides & 24 & 1.216 & 53 & 0.424 \\
\hline Asteraceae & Chaptalia runcinata & 2 & 0.101 & 6 & 0.048 \\
\hline Asteraceae & Chaptalia sinuata & 9 & 0.456 & 18 & 0.144 \\
\hline Asteraceae & Chevreulia acuminata & 1 & 0.051 & 2 & 0.016 \\
\hline Asteraceae & Chevreulia sarmentosa & 45 & 2.281 & 263 & 2.105 \\
\hline Asteraceae & Conyza monorchis & 3 & 0.152 & 5 & 0.040 \\
\hline Asteraceae & Elephantopus mollis & 1 & 0.051 & 5 & 0.040 \\
\hline Asteraceae & Facelis retusa & 23 & 1.166 & 41 & 0.328 \\
\hline Asteraceae & Gamochaeta americana & 13 & 0.659 & 30 & 0.240 \\
\hline Asteraceae & Gamochaeta coarctata & 5 & 0.253 & 9 & 0.072 \\
\hline Asteraceae & Gamochaeta falcata & 15 & 0.760 & 27 & 0.216 \\
\hline Asteraceae & Hypochaeris variegata & 16 & 0.811 & 45 & 0.360 \\
\hline Asteraceae & Micropsis spathulata & 59 & 2.990 & 296 & 2.369 \\
\hline Asteraceae & Panphalea heterophylla & 14 & 0.710 & 21 & 0.168 \\
\hline Asteraceae & Perezia multiflora ssp. sonchifolia & 2 & 0.101 & 5 & 0.040 \\
\hline Asteraceae & Porophyllum linifolium & 1 & 0.051 & 1 & 0.008 \\
\hline Asteraceae & Pterocaulon alopecuroides & 1 & 0.051 & 1 & 0.008 \\
\hline Asteraceae & Soliva pterosperma & 59 & 2.990 & 229 & 1.833 \\
\hline Asteraceae & Sommerfeltia spinulosa & 2 & 0.101 & 20 & 0.160 \\
\hline Asteraceae & Stenachaenium campestre & 2 & 0.101 & 3 & 0.024 \\
\hline Brassicaceae & Lepidium aletes & 4 & 0.203 & 5 & 0.040 \\
\hline
\end{tabular}


Marcelo Fett Pinto, Carlos Nabinger, Ilsi Iob Boldrini, Pedro Maria de Abreu Ferreira,

Robberson Bernal Setubal, Rafael Trevisan, Jean Kássio Fedrigo and Igor Justin Carassai

Appendix 2. Continuation.

\begin{tabular}{|c|c|c|c|c|c|}
\hline Family & Species/Subspecies/Variety & AF & $\begin{array}{l}\text { RF } \\
(\%)\end{array}$ & AC & $\begin{array}{l}\text { RC } \\
(\%)\end{array}$ \\
\hline Cactaceae & Gymnocalycium uruguayense & 1 & 0.051 & 1 & 0.008 \\
\hline Cactaceae & Parodia mammulosa & 1 & 0.051 & 5 & 0.040 \\
\hline Campanulaceae & Triodanis biflora & 2 & 0.101 & 2 & 0.016 \\
\hline Campanulaceae & Wahlenbergia linarioides & 10 & 0.507 & 14 & 0.112 \\
\hline Caryophyllaceae & Cerastium commersonianum & 1 & 0.051 & 1 & 0.008 \\
\hline Caryophyllaceae & Cerastium glomeratum & 2 & 0.101 & 2 & 0.016 \\
\hline Caryophyllaceae & Paronychia chilensis & 3 & 0.152 & 16 & 0.128 \\
\hline Cistaceae & Helianthemum brasiliense & 17 & 0.862 & 32 & 0.256 \\
\hline Commelinaceae & Tradescantia umbraculifera & 4 & 0.203 & 15 & 0.120 \\
\hline Convolvulaceae & Convolvulus laciniatus & 8 & 0.405 & 39 & 0.312 \\
\hline Convolvulaceae & Dichondra sericea & 38 & 1.926 & 188 & 1.505 \\
\hline Convolvulaceae & Evolvulus sericeus & 47 & 2.382 & 126 & 1.008 \\
\hline Cyperaceae & Abildgaardia ovata & 2 & 0.101 & 2 & 0.016 \\
\hline Cyperaceae & Bulbostylis capillaris & 2 & 0.101 & 3 & 0.024 \\
\hline Cyperaceae & Carex bonariensis & 2 & 0.101 & 3 & 0.024 \\
\hline Cyperaceae & Carex phalaroides & 17 & 0.862 & 37 & 0.296 \\
\hline Cyperaceae & Carex sororia & 1 & 0.051 & 10 & 0.080 \\
\hline Cyperaceae & Cyperus reflexus & 6 & 0.304 & 9 & 0.072 \\
\hline Cyperaceae & Eleocharis dunensis & 3 & 0.152 & 19 & 0.152 \\
\hline Cyperaceae & Eleocharis sellowiana & 1 & 0.051 & 2 & 0.016 \\
\hline Cyperaceae & Eleocharis viridans & 5 & 0.253 & 19 & 0.152 \\
\hline Euphorbiaceae & Euphorbia selloi & 1 & 0.051 & 1 & 0.008 \\
\hline Euphorbiaceae & Euphorbia sp. & 1 & 0.051 & 1 & 0.008 \\
\hline Euphorbiaceae & Euphorbia spathulata & 1 & 0.051 & 1 & 0.008 \\
\hline Euphorbiaceae & Euphorbia stenophylla & 5 & 0.253 & 6 & 0.048 \\
\hline Euphorbiaceae & Tragia geraniifolia & 2 & 0.101 & 6 & 0.048 \\
\hline Fabaceae & Adesmia incana & 1 & 0.051 & 75 & 0.600 \\
\hline Fabaceae & Galactia pretiosa & 33 & 1.673 & 82 & 0.656 \\
\hline Fabaceae & Macroptilium psammodes & 2 & 0.101 & 4 & 0.032 \\
\hline Fabaceae & Macroptilium prostratum & 1 & 0.051 & 2 & 0.016 \\
\hline Fabaceae & Rhynchosia diversifolia var. diversifolia & 11 & 0.558 & 30 & 0.240 \\
\hline Fabaceae & Rhynchosia senna & 1 & 0.051 & 1 & 0.008 \\
\hline Fabaceae & Stylosanthes montevidensis & 3 & 0.152 & 14 & 0.112 \\
\hline Fabaceae & Trifolium polymorphum & 47 & 2.382 & 355 & 2.841 \\
\hline Herreriaceae & Herreria montevidensis & 1 & 0.051 & 2 & 0.016 \\
\hline Iridaceae & Calydorea nuda & 1 & 0.051 & 1 & 0.008 \\
\hline Iridaceae & Cypella herbertii & 2 & 0.101 & 4 & 0.032 \\
\hline Iridaceae & Herbertia lahue & 3 & 0.152 & 4 & 0.032 \\
\hline
\end{tabular}


Appendix 2. Continuation.

\begin{tabular}{|c|c|c|c|c|c|}
\hline Family & Species/Subspecies/Variety & AF & $\begin{array}{l}\text { RF } \\
(\%)\end{array}$ & AC & $\begin{array}{l}\text { RC } \\
(\%)\end{array}$ \\
\hline Iridaceae & Sisyrinchium micranthum & 7 & 0.355 & 8 & 0.064 \\
\hline Iridaceae & Sisyrinchium minutiflorum & 6 & 0.304 & 7 & 0.056 \\
\hline Iridaceae & Sisyrinchium pachyrhizum & 8 & 0.405 & 11 & 0.088 \\
\hline Iridaceae & Sisyrinchium scariosum & 4 & 0.203 & 9 & 0.072 \\
\hline Juncaceae & Juncus capillaceus & 3 & 0.152 & 7 & 0.056 \\
\hline Juncaceae & Juncus microcephalus & 10 & 0.507 & 56 & 0.448 \\
\hline Lamiaceae & Scutellaria racemosa & 7 & 0.355 & 10 & 0.080 \\
\hline Linaceae & Cliococca selaginoides & 1 & 0.051 & 2 & 0.016 \\
\hline Lythraceae & Cuphea carthagenensis & 7 & 0.355 & 11 & 0.088 \\
\hline Lythraceae & Cuphea glutinosa & 14 & 0.710 & 28 & 0.224 \\
\hline Malvaceae & Ayenia mansfeldiana & 26 & 1.318 & 123 & 0.984 \\
\hline Malvaceae & Krapovickasia flavescens & 12 & 0.608 & 20 & 0.160 \\
\hline Malvaceae & Pavonia glechomoides & 16 & 0.811 & 68 & 0.544 \\
\hline Malvaceae & Pavonia hastata & 1 & 0.051 & 1 & 0.008 \\
\hline Moraceae & Dorstenia brasiliensis & 6 & 0.304 & 9 & 0.072 \\
\hline Onagraceae & Oenothera parodiana & 1 & 0.051 & 1 & 0.008 \\
\hline Orchidaceae & Habenaria parviflora & 1 & 0.051 & 2 & 0.016 \\
\hline Orobanchaceae & Agalinis communis & 2 & 0.101 & 3 & 0.024 \\
\hline Oxalidaceae & Oxalis bipartita subsp. bipartita & 1 & 0.051 & 1 & 0.008 \\
\hline Oxalidaceae & Oxalis eriocarpa & 5 & 0.253 & 19 & 0.152 \\
\hline Oxalidaceae & Oxalis lasiopetala & 2 & 0.101 & 2 & 0.016 \\
\hline Oxalidaceae & Oxalis sp. & 21 & 1.064 & 31 & 0.248 \\
\hline Plantaginaceae & Angelonia integerrima & 1 & 0.051 & 1 & 0.008 \\
\hline Plantaginaceae & Gratiola peruviana & 5 & 0.253 & 29 & 0.232 \\
\hline Plantaginaceae & Mecardonia tenella & 13 & 0.659 & 27 & 0.216 \\
\hline Plantaginaceae & Plantago brasiliensis & 1 & 0.051 & 2 & 0.016 \\
\hline Plantaginaceae & Plantago myosuros & 34 & 1.723 & 60 & 0.480 \\
\hline Plantaginaceae & Scoparia montevidensis & 2 & 0.101 & 3 & 0.024 \\
\hline Plantaginaceae & Veronica peregrina & 1 & 0.051 & 1 & 0.008 \\
\hline Poaceae & Agrostis hygrometrica & 1 & 0.051 & 1 & 0.008 \\
\hline Poaceae & Agrostis tandilensis & 1 & 0.051 & 4 & 0.032 \\
\hline Poaceae & Andropogon lateralis & 16 & 0.811 & 440 & 3.521 \\
\hline Poaceae & Andropogon ternatus & 17 & 0.862 & 115 & 0.920 \\
\hline Poaceae & Aristida echinulata & 11 & 0.558 & 121 & 0.968 \\
\hline Poaceae & Aristida murina & 10 & 0.507 & 49 & 0.392 \\
\hline Poaceae & Aristida venustula var. venustula & 44 & 2.230 & 206 & 1.649 \\
\hline Poaceae & Axonopus affinis & 19 & 0.963 & 155 & 1.240 \\
\hline Poaceae & Bothriochloa laguroides var. laguroides & 8 & 0.405 & 39 & 0.312 \\
\hline
\end{tabular}


Marcelo Fett Pinto, Carlos Nabinger, Ilsi Iob Boldrini, Pedro Maria de Abreu Ferreira,

Robberson Bernal Setubal, Rafael Trevisan, Jean Kássio Fedrigo and Igor Justin Carassai

Appendix 2. Continuation.

\begin{tabular}{|c|c|c|c|c|c|}
\hline Family & Species/Subspecies/Variety & AF & $\begin{array}{l}\text { RF } \\
(\%)\end{array}$ & AC & $\begin{array}{l}\text { RC } \\
(\%)\end{array}$ \\
\hline Poaceae & Bouteloua megapotamica & 1 & 0.051 & 5 & 0.040 \\
\hline Poaceae & Briza minor & 27 & 1.368 & 132 & 1.056 \\
\hline Poaceae & Chascolytrum poomorphum & 8 & 0.405 & 15 & 0.120 \\
\hline Poaceae & Chascolytrum rufum & 5 & 0.253 & 10 & 0.080 \\
\hline Poaceae & Chascolytrum subaristatum & 18 & 0.912 & 81 & 0.648 \\
\hline Poaceae & Calamagrostis viridiflavescens var. viridiflavescens & 1 & 0.051 & 1 & 0.008 \\
\hline Poaceae & Chloris grandiflora & 4 & 0.203 & 24 & 0.192 \\
\hline Poaceae & Mnesithea selloana & 41 & 2.078 & 316 & 2.529 \\
\hline Poaceae & Cynodon dactylon var. dactylon & 1 & 0.051 & 1 & 0.008 \\
\hline Poaceae & Danthonia cirrata & 23 & 1.166 & 149 & 1.192 \\
\hline Poaceae & Danthonia montevidensis & 8 & 0.405 & 190 & 1.521 \\
\hline Poaceae & Dichanthelium sabulorum var. sabulorum & 12 & 0.608 & 132 & 1.056 \\
\hline Poaceae & Eragrostis bahiensis & 1 & 0.051 & 2 & 0.016 \\
\hline Poaceae & Eragrostis lugens & 6 & 0.304 & 16 & 0.128 \\
\hline Poaceae & Eragrostis neesii var. neesii & 31 & 1.571 & 103 & 0.824 \\
\hline Poaceae & Eustachys brevipila & 9 & 0.456 & 31 & 0.248 \\
\hline Poaceae & Hordeum euclaston & 1 & 0.051 & 1 & 0.008 \\
\hline Poaceae & Melica brasiliana & 1 & 0.051 & 1 & 0.008 \\
\hline Poaceae & Melica rigida & 7 & 0.355 & 73 & 0.584 \\
\hline Poaceae & Microchloa indica & 12 & 0.608 & 111 & 0.888 \\
\hline Poaceae & Paspalum dilatatum & 7 & 0.355 & 46 & 0.368 \\
\hline Poaceae & Paspalum indecorum & 27 & 1.368 & 647 & 5.178 \\
\hline Poaceae & Paspalum lepton & 6 & 0.304 & 71 & 0.568 \\
\hline Poaceae & Paspalum notatum & 62 & 3.142 & 638 & 5.106 \\
\hline Poaceae & Paspalum plicatulum & 13 & 0.659 & 49 & 0.392 \\
\hline Poaceae & Paspalum pumilum & 2 & 0.101 & 25 & 0.200 \\
\hline Poaceae & Paspalum urvillei & 2 & 0.101 & 7 & 0.056 \\
\hline Poaceae & Phalaris angusta & 4 & 0.203 & 9 & 0.072 \\
\hline Poaceae & Piptochaetium bicolor var. bicolor & 1 & 0.051 & 5 & 0.040 \\
\hline Poaceae & Piptochaetium montevidense & 55 & 2.788 & 488 & 3.906 \\
\hline Poaceae & Piptochaetium stipoides var. stipoides & 40 & 2.027 & 326 & 2.609 \\
\hline Poaceae & Piptochaetium stipoides var. chaetophorum & 2 & 0.101 & 20 & 0.160 \\
\hline Poaceae & Poa апnиа & 1 & 0.051 & 1 & 0.008 \\
\hline Poaceae & Poa lanigera & 1 & 0.051 & 1 & 0.008 \\
\hline Poaceae & Schizachyrium imberbe & 9 & 0.456 & 72 & 0.576 \\
\hline Poaceae & Schizachyrium spicatum & 13 & 0.659 & 75 & 0.600 \\
\hline Poaceae & Setaria parviflora & 16 & 0.811 & 64 & 0.512 \\
\hline Poaceae & Setaria vaginata var. vaginata & 2 & 0.101 & 5 & 0.040 \\
\hline
\end{tabular}


Appendix 2. Continuation.

\begin{tabular}{|c|c|c|c|c|c|}
\hline Family & Species/Subspecies/Variety & AF & $\begin{array}{l}\text { RF } \\
(\%)\end{array}$ & AC & $\begin{array}{l}\text { RC } \\
(\%)\end{array}$ \\
\hline Poaceae & Sporobolus indicus & 1 & 0.051 & 2 & 0.016 \\
\hline Poaceae & Steinchisma hians & 17 & 0.862 & 67 & 0.536 \\
\hline Poaceae & Stipa setigera var. setigera & 15 & 0.760 & 128 & 1.024 \\
\hline Poaceae & Trachypogon montufarii var. montufarii & 34 & 1.723 & 487 & 3.898 \\
\hline Poaceae & Tridens hackelii & 1 & 0.051 & 1 & 0.008 \\
\hline Poaceae & Tripogon spicatus & 1 & 0.051 & 4 & 0.032 \\
\hline Poaceae & Vulpia bromoides & 38 & 1.926 & 278 & 2.225 \\
\hline Polygalaceae & Polygala bonariensis & 1 & 0.051 & 5 & 0.040 \\
\hline Polygalaceae & Polygala molluginifolia & 3 & 0.152 & 11 & 0.088 \\
\hline Polygalaceae & Polygala pulchella & 24 & 1.216 & 43 & 0.344 \\
\hline Primulaceae & Anagallis minima & 14 & 0.710 & 28 & 0.224 \\
\hline Primulaceae & Pelletiera serpyllifolia & 3 & 0.152 & 16 & 0.128 \\
\hline Rubiaceae & Galium richardianum & 18 & 0.912 & 21 & 0.168 \\
\hline Rubiaceae & Richardia humistrata & 33 & 1.673 & 250 & 2.001 \\
\hline Rubiaceae & Richardia stellaris & 38 & 1.926 & 164 & 1.313 \\
\hline Rubiaceae & Spermacoce capitata & 14 & 0.710 & 23 & 0.184 \\
\hline Rubiaceae & Spermacoce verticillata & 1 & 0.051 & 2 & 0.016 \\
\hline Solanaceae & Calibrachoa ovalifolia & 1 & 0.051 & 1 & 0.008 \\
\hline Solanaceae & Nicotiana bonariensis & 3 & 0.152 & 31 & 0.248 \\
\hline Turneraceae & Turnera sidoides subsp. integrifolia & 12 & 0.608 & 22 & 0.176 \\
\hline Verbenaceae & Glandularia nana & 1 & 0.051 & 1 & 0.008 \\
\hline Verbenaceae & Glandularia subincana & 2 & 0.101 & 6 & 0.048 \\
\hline Verbenaceae & Glandularia tenera & 1 & 0.051 & 1 & 0.008 \\
\hline Verbenaceae & Lippia villafloridana & 4 & 0.203 & 18 & 0.144 \\
\hline Verbenaceae & Verbena gracilescens & 2 & 0.101 & 2 & 0.016 \\
\hline Verbenaceae & Verbena montevidensis & 2 & 0.101 & 2 & 0.016 \\
\hline Violaceae & Hybanthus parviflorus & 1 & 0.051 & 3 & 0.024 \\
\hline
\end{tabular}

